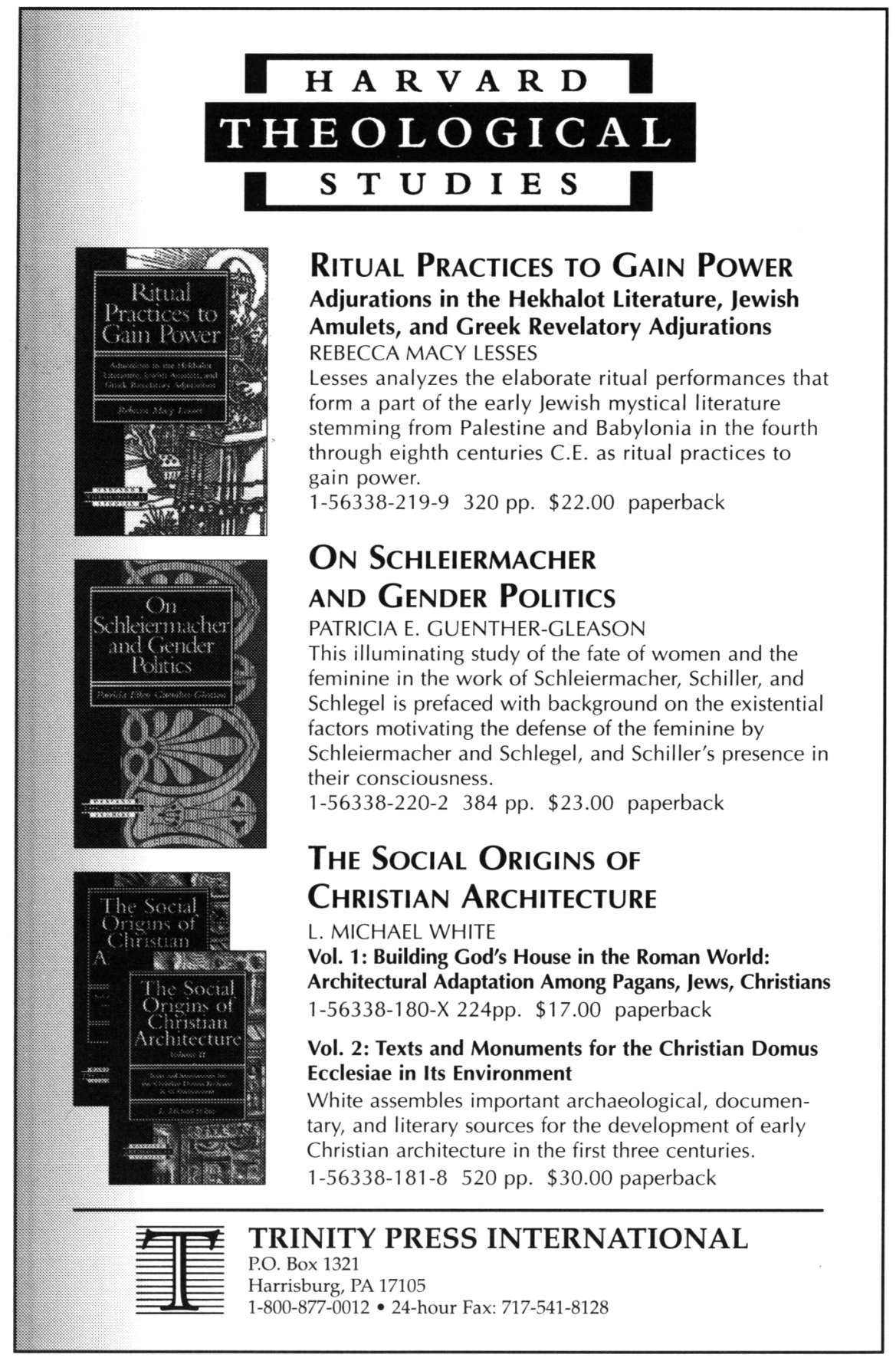




\section{Ii $\mathbf{T}_{\mathbf{R}}$ \\ Harvard Theological Review}

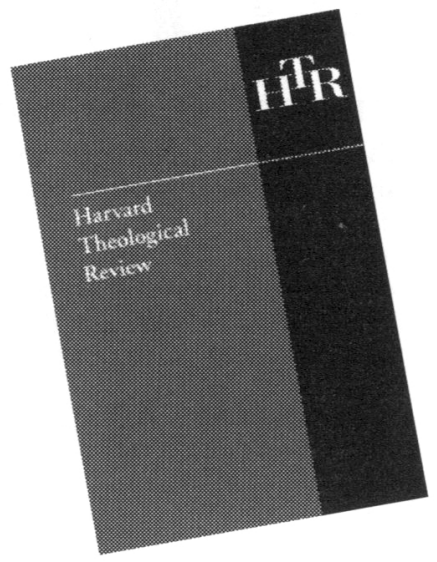

The scope of the Review

embraces theology, the history and philosophy of religion, and cognate subjects. It seeks to publish thoughtful and original research on the cutting-edge of contemporary scholarship, studies that contribute to the enlargement of knowledge or the advancement of thought.

\section{Recent Articles}

i. Michael White, "Synagogue and Society in Imperial Ostia:Archaeological and Epigraphic Evidence”

J. J.M. Roberts, "Whose Child Is This? Reflections on the Speaking Voice in Isaiah 9:5"

John S. Kloppenborg, "The Sayings Gospel Q and the Quest of the Historical Jesus"

se. David C. Lamberth, "Intimations of the Finite: Thinking Pragmatically at the End of Modernity"

The Review is published four times each year and costs $\$ 25$ per year for individuals, $\$ 50$ per year for institutions, with a $\$ 5$ additional charge for mailing journals outside the continental United States.
Subscription inquires should be addressed to:

Harvard Theological Review 45 Francis Avenue Cambridge, Massachusetts 


\section{1:1 JANUARY 1998}

3 The So-Called Therapeutae of De Vita Contemplativa Joan E. Taylor and Philip R. Davies

25 Maimonides on Freedom of the Will and Moral Responsibility

Moshe Sokol

41 Vincent Ferrer's Beati Petri Apostoli: Canonical and Apocryphal Sources in Popular Vernacular Preaching Alberto Ferreiro

59 Friedrich Schleiermacher on the Central Place of Worship in Theology Theodore Vial

75 Communicative Theory and Theology: A Reconsideration K. L. Afrasiabi

Notes and Observations

89 Bona Cogitare: An Epicurean Consolation in Phil 4:8-9 Paul Holloway

97 Books Received 